\title{
SISTEM TERITORIAL AREA DAGANG DI PASAR BERINGHARJO
}

\author{
Alifa Mifty Fala \& Ismael Setiawan* \\ Program Studi Desain Interior Institut Seni Indonesia Yogyakarta
}

\begin{abstract}
ABSTRAK
Pasar merupakan ruang publik yang didalamnya terjadi berbagai aktivitas dan interaksi sosial di antara pelakunya. Interaksi tersebut memungkinkan terjadinya konflik di antara pelakunya khususnya untuk mempertahankan area teritori masing-masing. Penelitian ini memfokuskan bagaimana para pedagang di pasar Beringharjo membentuk territorial selama beraktivitas dagang. Metode kualitatif digunakan untuk menemukan fakta-fakta di lapangan. Sampel dipilih secara acak berdasarkan komoditi yang dijual. Penelitian ini menunjukkan bahwa sistem teritorial yang berlaku di pasar Beringharjo ini sangat unik, tidak mengenal hirarki ruang tetapi lebih dipengaruhi oleh perilaku dan sikap yang berlaku di kehidupan masyarakat khususnya budaya Jawa. Kaidah-kaidah kerukunan, rasa hormat diterapkan untuk menciptakan keselarasan dalam mengatur sistem teritori dagang di lingkungkan pasar Beringharjo.
\end{abstract}

Kata Kunci: teritori, pasar, budaya Jawa

\section{PENDAHULUAN}

Pasar merupakan ruang publik yang menjadi tempat terjadinya jual beli dan pertukaran barang maupun jasa. Pasar memiliki agen-agen, yaitu pedagang, pembeli, dan pengelola. Ketiga agen pasar ini memiliki aktivitas masing-masing baik yang berhubungan mau pun tidak. Aktivitasaktivitas ini pada akhirnya memberi ruang untuk interaksi sosial diantara para agen tersebut. Demikian juga dengan Pasar Beringharjo, merupakan pasar induk tradisional yang berada di Yogyakarta. Pasar ini dibangun untuk memenuhi asas catur tunggal yang diterapkan oleh pemerintah Kraton Yogyakarta dalam menata kota Yogyakarta. Pasar ini dijadikan pusat perekonomian yang memberdayakan masyarakat sekitar. Pembagian area dagang yang terjadi di Pasar Beringharjo pada awalnya dibagi secara cuma-cuma oleh pengelola Kraton Ngayogyakarta.

Teritorialitas merupakan perilaku dimana seseorang ingin menjadi diri sendiri atau menyatakan diri bahwa ia memiliki dan melakukan pertahanan terhadap suatu area. Teritorialitas ini merupakan sebuah perilaku dasar yang dimiliki oleh setiap manusia. Berdasarkan daerah teritorinya, manusia bisa menunjukkan daerah kekuasaan dimana ia bisa memiliki daerah tersebut. oleh beberapa ahli seperti Altman, Chemers, Brown, dan Taylor definisi dari teritorialitas adalah suatu set perilaku kognisi yang ditampilkan oleh individu atau kelompok yang didasarkan pada pemahaman atas kepemilikan ruang fisiknya (Halim, 2006).

Kekuasaan merupakan salah satu hal yang diatur oleh masyarakat Jawa dalam 2 kaidah kehidupan masyarakat Jawa. Menurut (Magnis Suseno, 1988), ada dua kaidah kehidupan dalam masyarakat Jawa yaitu keselarasan dan kekuasaan. Asas keselarasan merupakan asas mengenai kerukunan sosial. Kerukunan sosial dalam etika Jawa berarti lebih mementingkan kepentingan bersama daripada pribadi, sedangkan asas kekuasaan lebih mengatur mengenai rasa hormat pada apa saja yang merupakan ciptaan Tuhan. Kaidah tersebut berlaku juga di Pasar Beringharjo yang merupakan pasar gedhe bagi masyarakat Jawa khususnya di daerah Yogyakarta, sehingga tatanan yang berlaku di sana mendapatkan pengaruh dari perilaku dan etika masyarakat Jawa disekitarnya.

Para pedagang di Pasar Beringharjo mempunyai banyak cara untuk membatasi area dagang mereka dengan milik orang lain. Baik pada kios dengan sekat-sekat yang sudah dibagi oleh pengelola maupun yang tanpa sekat. Dalam hal ini diperkirakan terdapat unsur-unsur kaidah kehidupan masyarakat Jawa yang dalam prakteknya digunakan dalam sistem pembagian teritori di mana teritori area dagang masing-masing pedagang yang tidak saling menganggu satu sama lain dalam melakukan kegiatan jual-beli.

Melihat fenomena yang sudah dipaparkan di atas, terbentuknya sistem territorial pada sebuah area publik seperti pasar bisa terbentuk oleh faktor fisik maupun non fisik atau sosial. Terlebih lagi pasar Beringharjo merupakan ruang publik yang berada di daerah dengan masyarakat 
Jawa yang dikenal yang masih dipegang teguh kaidah-kaidah hidup sampai saat ini. Melalui evaluasi serta pemahaman mengenai sistem territorial pada pasar Beringharjo ini diharapkan akan memberi kemudahan dalam proses pengembangan riset dan desain interior ruang publik khususnya pasar tradisional yang masih terkait dengan masyarakat sekitar.

\section{METODE PENELITIAN}

Metode yang digunakan dalam penelitian ini adalah metode kualitatif. Penelitian kualitatif merupakan prosedur penelitian yang menghasilkan data deskriptif berupa kata-kata tertulis atau lisan dari orang-orang dan perilaku yang dapat diamati. Pendekatan ini diarahkan pada latar dan individu tersebut secara utuh (Moleong, 2009). Sesuai dengan metode penelitian kualitatif maka penelitian ini menggunakan latar alamiah dengan menafsirkan fenomena yang terjadi melalui metode wawancara terbuka untuk memahami sikap, pandangan, perasaan, dan perilaku individu atau sekelompok orang. Metode ini dilakukan untuk menemukan fakta-fakta yang terjadi dalam sebuah objek (populasi) atau sebagian (sampel). Selanjutnya fakta-fakta tersebut akan digambarkan sebagaimana terjadinya pada kenyataan. Penelitian ini memusatkan perhatian pada masalah-masalah yang ada pada saat penelitian dilakukan atau bersifat aktual. Pada akhir penelitian ini akan memberikan rekomendasi desain yang memungkinkan untuk diterapkan dalam area dagang di pasar Beringharjo.

Populasi penelitian ini adalah seluruh area dagang di Pasar Beringharjo, Yogyakarta. Area dagang ini meliputi 5.441 los dengan 6.000 pedagang. Komoditi yang dijual pada jumlah pedagang tersebut diantaranya adalah kain dan baju batik; suvenir; perlengkapan dapur; barang antik dan kuno; aneka tas; kuliner tradisional; bumbu dan rempah; gamis dan kaftan; jual-beli emas; sayur, buah, daging, serta ikan; dan barang bekas. Sampel penelitian ini diambil secara acak dengan kriteria pemilihan berdasarkan komoditas yang dijual, diantaranya: bumbu dan rempah, kerajinan atau souvenir, dan pakaian.

\section{PEMBAHASAN}

Pada umumnya pasar-pasar milik pemerintah yang ada di Yogyakarta area dagang ditentukan secara resmi oleh pengelola pasar. Demikian juga dengan area dagang di pasar Beringharjo pada dasarnya setiap pedagang memiliki area resmi dengan luasan tertentu yang telah ditentukan oleh pengelola pasar, akan tetapi area tersebut tidak ditandai secara fisik dengan pembatas namun ada aturan atau kesepakatan tidak resmi yang terbentuk di antara para pedagang mengenai batas teritori area dagang masing-masing. Batas-batas teritori non fisik tersebut terbentuk secara alami di dalam kehidupan sosial mereka. Sistem kebudayaan dan etika masyarakat Jawa mempengaruhi terbentuknya kesepakatan dalam mengatur teritori area dagang tersebut.

\section{Sistem Teritorial di Pasar Beringharjo}

Bila dikaitkan dengan pendapat Halim (2006) di mana perilaku teritorial diasosiasikan dengan teritori primer, sekunder, dan publik. Pada kenyataannya terbentuknya teritorial dagang di Pasar Beringharjo tidak mengenal hirarki tersebut tetapi terbentuk karena proses, pertama pedagang akan memilih untuk membeli luasan modular yang ditawarkan oleh pengelola, kemudian pengelola akan mengelompokkannya sesuai dengan jenis komoditi yang dijual. Selanjutnya pedagang mendapatkan kios melalui sistem undian yang diambil secara acak. Teritorial yang berlaku di pasar Beringharjo tidak hanya untuk pedagang resmi tetapi juga pedagang tidak resmi, dan pengunjung. Perilaku menciptakan teritori ini juga berbeda-beda tergantung pada jenis komoditi yang dijual oleh pedagang.

Seiring waktu masing-masing pedagang menandai teritori area dagangnya dengan penanda fisik yang terlihat secara visual berupa partisi, rolling door atau sekat-sekat dengan bentuk lain untuk menunjukkan batasan antara wilayahnya dengan orang lain. Mereka membentuk batasanbatasan tersebut dengan berbagai macam cara. Salah satu contohnya adalah dengan menggantungkan pakaian dagangan mereka pada sebuah jarring-jaring besi vertikal setinggi 2-3 meter. Selain berfungsi sebagai tempat mendisplay pakaian dagangan juga untuk menunjukkan teritori mereka. 
Penerapan azas kerukunan masyarakat Jawa yang dikemukakan Magnis Suseno (1988), "Rukun adalah kekuatan ideal yang diharapkan dapat mempertahankan seтиa hubungan social. Rukun merujuk pada perilaku untuk tenang satu sama lain dan mengesampingkan unsur-unsur perselisihan".

Azas kerukunan tersebut dalam prakteknya, digunakan oleh para pedagang dalam mempertahankan wilayah teritori masing-masing dengan tetap saling menjaga ketenangan satu sama lain dan berusaha mengesampingkan unsur-unsur perselisihan. Hasil penelitian ini menunjukkan bahwa bentuk perilaku territorial dipengaruhi oleh sikap dan sifat masyarakat sekitar, khususnya masyarakat Jawa. Meskipun tidak semua pedagang merupakan orang Jawa, namun karena sudah lama hidup di tanah Jawa, mereka sudah banyak menyesuaikan diri dengan masyarakat Jawa. Pada prakteknya, sikap-sikap masyarakat Jawa yang menjunjung tinggi keselarasan ini memunculkan beberapa sistem yang digunakan untuk menyelaraskan satu sama lain individu. Para pedagang berusaha saling menghormati orang lain dan menganggap mereka sebagai keluarga sendiri, sehingga mereka tidak akan mengambil hak orang lain ataupun berusaha menyingkirkan kewajiban milik mereka sendiri. Munculnya beberapa perjanjian antara satu dengan yang lain merupakan wujud kebersamaan yang terasa di pasar Beringharjo. Perjanjian ini biasanya meliputi bagaimana menjaga barang dagangan, bagaimana mendisplay barang dagangan, seberapa luas area yang mereka butuhkan dan bagaimana caranya menyesuaikan dengan tetangga yang ada.

Penyesuaian untuk menciptakan keselarasan dalam pembagian teritori tidak hanya dilakukan dengan sesama pedagang tetapi juga dilakukan dengan pengelola pasar. Seperti adanya aturan yang memperbolehkan display dagangan melebihi 3-4 tegel di luar dari toko mereka masingmasing, atau izin pembuatan pembatas fisik (partisi, rolling door, dsb) yang harus mendapatkan izin berupa tanda tangan dari tetangga di depan, samping kanan dan kiri, serta belakang si pedagang tersebut. Seiring berjalannya waktu, beberapa perubahan yang terjadi pada sistem territorial pasar Beringharjo salah satu perubahan yang sangat signifikan terjadi adalah pada bagian fisik. Perubahan ini melingkupi pada bagaimana cara para pedagang dalam menunjukkan kekuasaannya atas suatu daerah dagangnya. Seperti yang sudah dipaparkan sebelumnya, pemerintah melalui pengelola pasar memberi lahan berupa modular pada para pedagang untuk mereka berdagang, tanpa adanya pembatas resmi kemudian para pedagang membentuk sendiri pembatas-pembatas tersebut.

Perubahan ini tentu tidak terlepas dari faktor non-fisik yang terjadi pada para pedagang tersebut. Pada penelitian ini, diketahui bahwa terdapat sebuah peraturan yang terbentuk atas beberapa perubahan yang hendak dilakukan oleh para pedagang, yaitu peraturan mengenai pembangunan partisi atau rolling door atau pembatas lainnya. Peraturan ini menuntut para pedagang yang hendak membangun pembatas massif seperti partisi atau rolling door harus mendapatkan ijin dari tetangga depan, belakang, serta samping kanan dan kiri mereka. Peraturan ini dibuat untuk menjaga kerukunan masing-masing pedagang, agar satu sama lain tidak merasa barang dagangannya tidak tersabotase oleh pedagang lain yang memiliki pembatas massif. Terciptanya perasaan nyaman di antara para pedagang, mengkondisikan suasana pasar yang nyaman bagi setiap agen pasar yang berkegiatan di dalamnya.

Sikap kekeluargaan ditunjukkan dalam sistem teritori di pasar beringharjo. Hal ini terlihat ketika pedagang saling memaklumi satu sama lain mengenai perubahan teritori milik tetangganya. Mereka akan menganggap pelanggaran territorial secara fisik bukan masalah selama pelanggaran tersebut tidak dilakukan dalam jangka waktu yang lama atau si tetangga menyatakan ijin pada sebelumnya. Hasil wawancara menunjukkan bahwa pedagang tidak merasa keberatan bila teritorinya dilanggar karena mereka menganggap tetangga sebagai keluarga yang secara fisik dekat dengan mereka. Sehingga apapun yang terjadi di antara beberapa pedagang yang berdekatan akan bisa diselesaikan dengan kekeluargaan.

Sikap tidak mau berkonflik serta rasa hormat merupakan hal lain yang tampak pada pasar Beringharjo ini. Satu sama lain pedagang meskipun sudah mempercayai, mereka tetap saja akan merasa 'tahu diri'. Seperti prinsip masyarakat Jawa yang mengatakan bahwa segala sesuatu adalah baik, dan hal buruk hanya datang dari orang yang tidak mengetahuinya. Para pedagang terlihat mampu bersikap tenang dengan saling mempercayai satu sama lain. Mereka tidak akan merasa takut barang akan dicuri meskipun tidak menggunakan penutup yang cukup rapat dalam komoditi bumbu dan rempah. Mereka menganggap para pedagang adalah manusia yang sudah dewasa dan tahu mana yang seharusnya dan tidak seharusnya dilakukan oleh orang pada umumnya. Kembali lagi pada sikap 'tahu diri' pada masing-masing pedagang juga, mereka akan tetap berada pada jalur masingmasing meskipun memiliki kepentingan yang sama. 


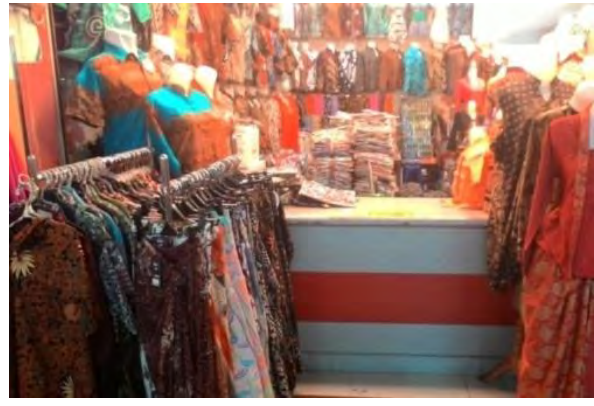

Gambar 19 Pembatas pedagangpengunjung (Sumber: Alifa MF, 2018)

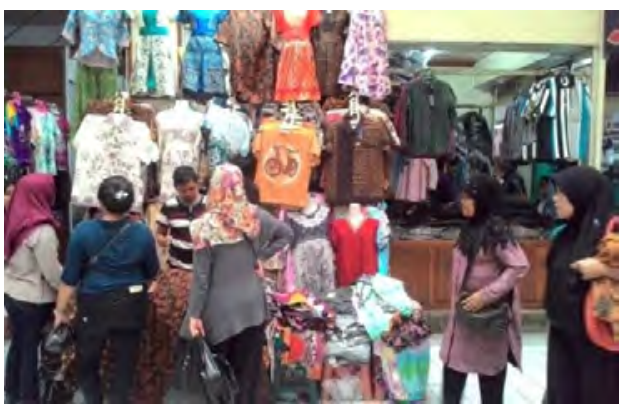

Gambar 21 Kios pakaian pada lantai 1 (Sumber: Alifa MF, 2018)

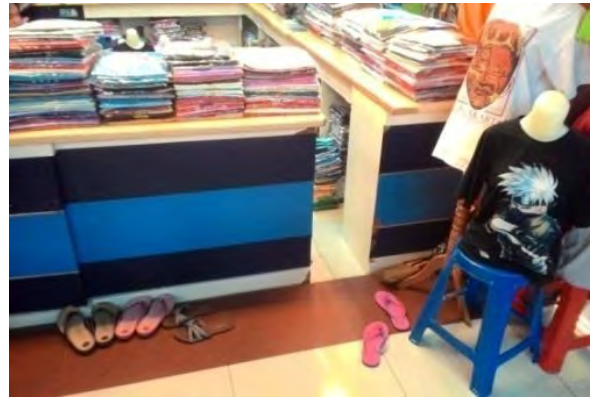

Gambar 20 Pembatas pedagang-pengunjung (Sumber: Alifa MF, 2018)

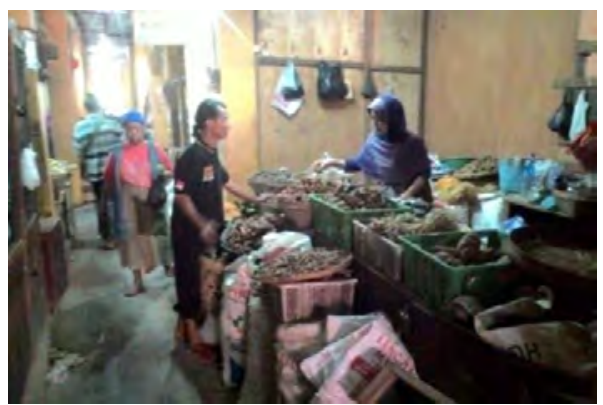

Gambar 22 Kios bumbu \& rempah pada lantai 2 (Sumber: Alifa MF, 2018)

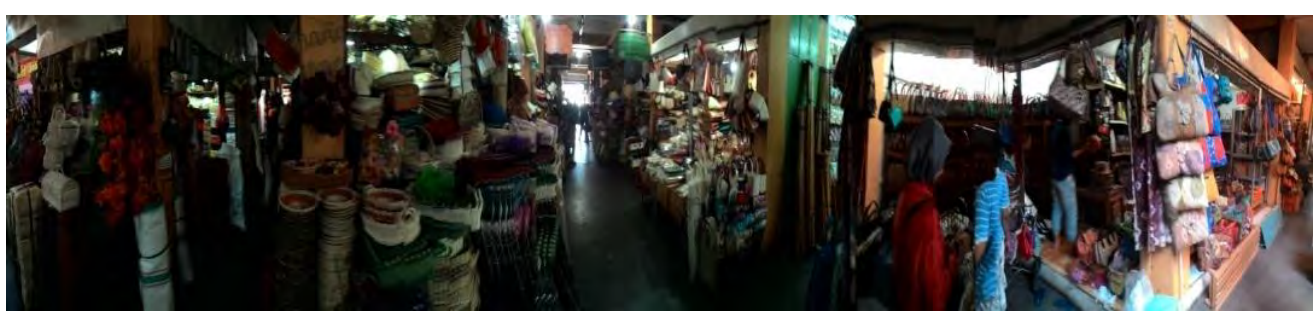

Gambar 23 Tampak panorama kios-kios kerajinan dan souvenir lantai 3.

(Sumber: Alifa $M F, 2018$ ) 


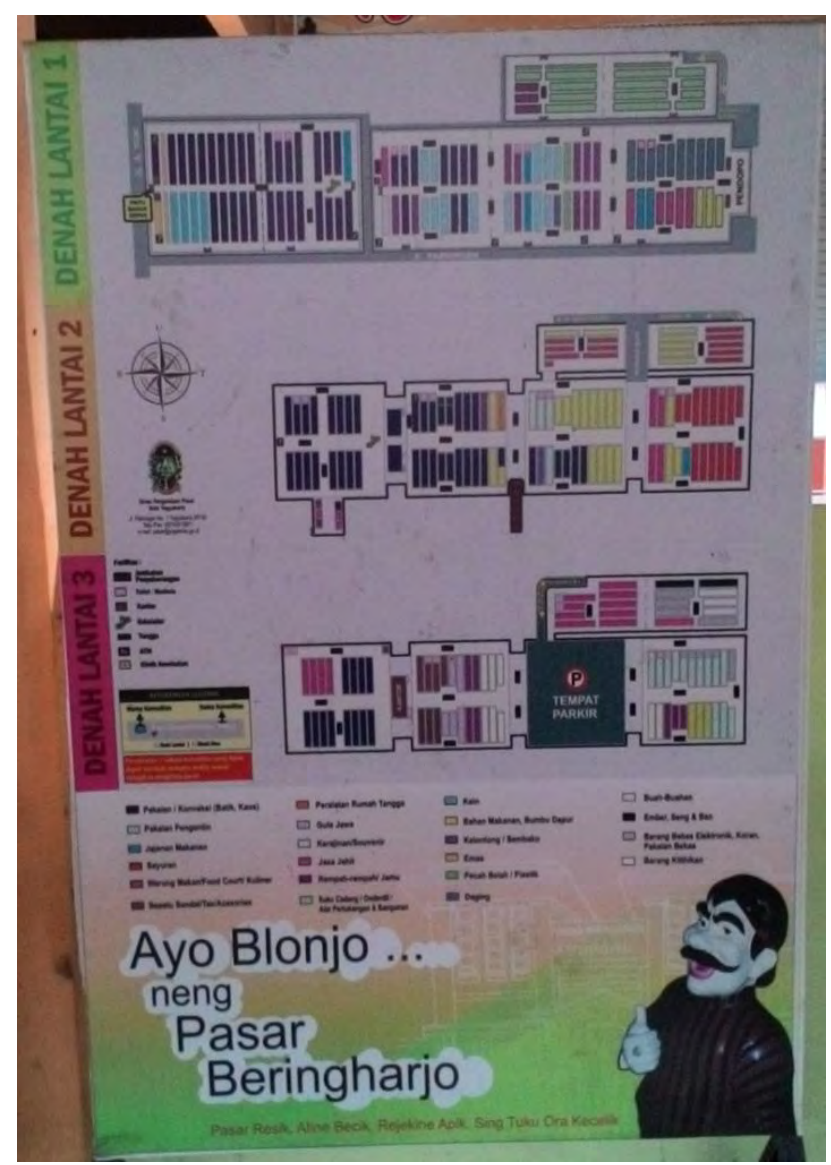

Gambar 24 Denah pasar Beringharjo (Sumber: Alifa MF, 2018)

\section{Rekomendasi Desain pada Sistem Teritorial di Pasar Beringharjo}

Teritorial yang terbentuk dalam masyarakat tergantung pada rangkaian perilaku berpikir dari individu atau kelompok yang didasarkan pada pemahaman atas kepemilikan ruang fisiknya. Pemahaman atas kepemilikan ruang fisik tersebut berkaitan dengan kekuasaan sehingga akan mengatur manusia lain yang berada dalam wilayahnya. Beberapa pendapat yang menyatakan adanya keterkaitan antara teritorial dengan kebiasaan-kebiasaan yang menjadi budaya bagi masyarakat sekitar (Hall, 1990) khususnya dalam kehidupan bermasyarakat Jawa yang menganut kaidah keselarasan dan kekuasaan (Magnis Suseno, 1988). Hal ini semakin memberikan penjelasan bahwa masyarakat Jawa merupakan masyarakat yang fleksible di mana mereka bisa menyesuaikan dengan aturan tetapi mempunyai keleluasaan untuk bertindak sesuai dengan kaidah keselarasan. Oleh karena itu, prinsip fleksibilitas dalam pengaturan area menjadi kata kunci untuk rekomendasi desain pada penelitian ini dengan harapan mampu memenuhi kebutuhan teritori para pedagang, juga tidak mengubah kondisi keselarasan sosial yang berada di sekitarnya. 


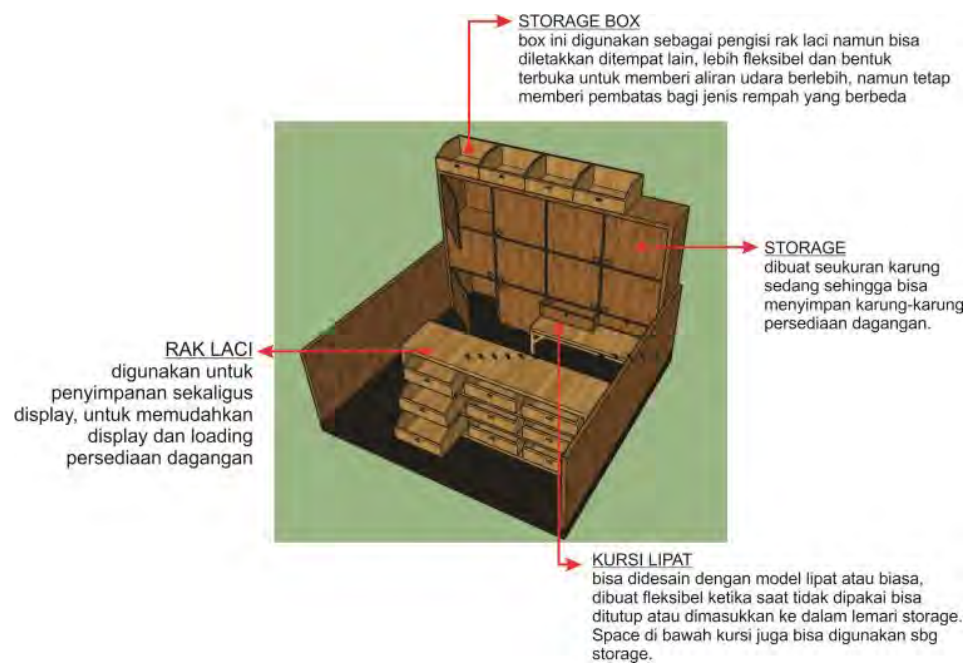

Gambar 25 Ilustrasi Rekomendasi Desain Kios Bumbu, Rempah, dan Makanan Ringan (Sumber: Alifa MF, 2018)

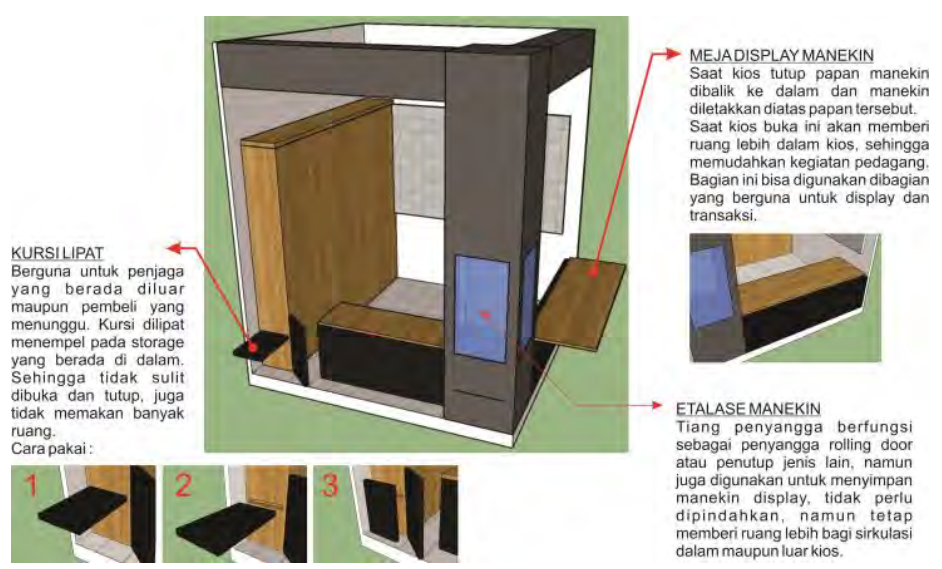

Gambar 26 Ilustrasi Rekomendasi Desain Kios Pakaian (Sumber: Alifa MF, 2018)

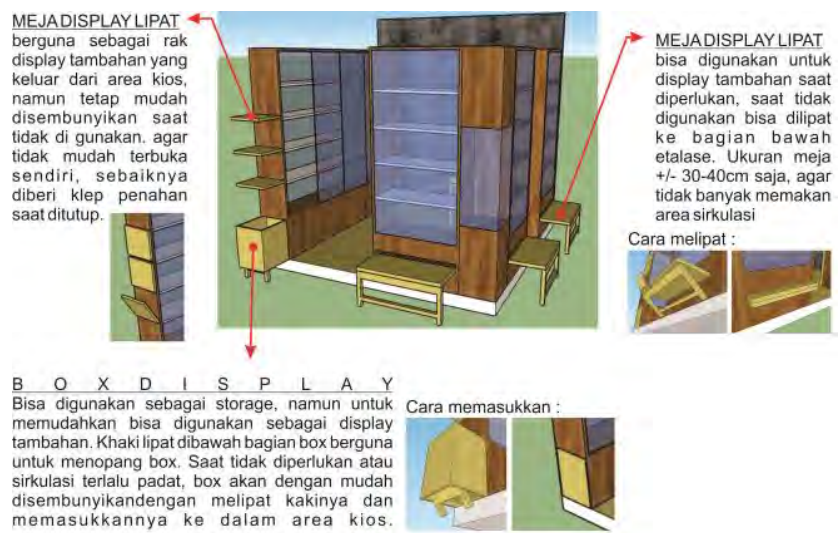

Gambar 27 Ilustrasi rekomendasi desain kio (Sumber: Alifa MF, 2018) 


\section{KESIMPULAN}

Sikap bagaimana para pedagang berusaha melindungi hak maupun kewajiban mereka didalam Pasar Beringharjo tercermin dalam cara mereka menciptakan territorial di area dagang. Teritorial di pasar Beringharjo tidak mengenal hirarki ruang tetapi lebih dipengaruhi oleh sikap dan perilaku yang berkaitan dengan budaya di sekitar kehidupan masyarakat khususnya masyarakat Jawa yang meyelaraskan antara kerukunan, rasa hormat dan kepentingan untuk menentukan teritorialnya. Asas-asas tersebut yang diterapkan dalam kehidupan masyarakat di pasar Beringharjo untuk menciptakan keselarasan sosial, kenyamanan sosial di antara semua agen di dalam pasar, terutama hubungan antar pedagang resmi maupun tidak resmi.

\section{DAFTAR PUSTAKA}

Halim, D. (2006). Psikologi Arsitektur. Jakarta: PT Gramedia Widiarsa Indonesia.

Hall, E. T. (1990). The Hidden Dimension. New York, United States: Bantam Doubleday Dell Publishing Group I1.

Magnis Suseno, F. (1988). Etika Jawa. Jakarta: PT Gramedia Widiarsa Indonesia.

Moleong, L. (2009). Metodologi Penelitian Kualitatif. Bandung: PT Remaja Rosdakarya Offset. 